Журнал«Герстективита інновації наукц»

(Серія«Гедагогіка», Серія«Гцихологія», Серія«Медицинв»

№2(7) 2022

УДК 378.147

https://doi.org/10.52058/2786-4952-2022-2(7)-444-455

Максимова Ольга Павлівна кандидат педагогічних наук, доцент кафедри мовних і гуманітарних дисциплін, кафедра мовних і гуманітарних дисциплін № 2, Донецький національний медичний університет, вул. Велика Перспективна 1, м. Кропивницький, 25000, тел.: (067) 520-14-88, https://orcid.org/0000-0001-8997-4394

Апалат Ганна Павлівна кандидат філологічних наук, доцент кафедри германських мов та методик їхнього навчання, кафедра германських мов та методик їхнього навчання, Центральноукраїнський державний педагогічний університет імені Володимира Винниченка, вул. Шевченка 1, м. Кропивницький, 25006, тел.: (095) 386-03-62, https://orcid.org/0000-0003-1464-7174

\title{
РОЗВИТОК КОМПЕТЕНТНОСТІ В ПИСЬМІ В СТАРШІЙ ШКОЛІ
}

Анотація. Компетентність у письмі є одним із компонентів іншомовної комунікативної компетентності. В сучасній методиці письмо розглядається не лише як засіб навчання, але й як засіб і спосіб спілкування, пізнання та творчості. Підхід до писемного мовлення як до допоміжного засобу навчання іноземної мови зумовив недостатню кількість практичних завдань на кожному етапі навчання комунікативного письма у шкільних підручниках та навчальних посібниках, що й зумовило актуальність дослідження особливостей навчання писати листи в старшій школі.

Пропонують чотири підходи до навчання письма певного жанру на завершальному етапі навчання: текстовий, жанровий, процесуальний, інтегрований. Інтегрований підхід, який ми пропонуємо застосовувати для навчання письма, поєднує риси вищеназваних трьох - навчання мовних засобів, ретельне опрацювання текстів-моделей; навчання письма, орієнтованого на адресата, урахування соціального контексту; навчання поетапного породження дискурсу. Для навчання писемного мовлення пропонують такі типи вправ: підготовчі (мовні й умовно-комунікативні) і комунікативні (мовленнєві) вправи.

Підсистема вправ для навчання написання листів різних жанрів має включати два етапи: підготовчий та мовленнєвий. Етап ознайомлення ознайомлення учнів 3 позамовними стандартами написання офіційних та приватних листів: Етап навчання - застосовуються вправи для формування навичок побудови текстів листів. Комунікативний етап - учні продукують тексти власних листів.

Навчання писемної діяльності в старшій школі має на меті розвиток комунікативного письма. На даному етапі учні старших класів виконують завдання: написати лист знайомій людині (за поданою ситуацією). Для навчання написання листа застосовується підсистема вправ, що включає етап 
ознайомлення, етап навчання та комунікативний етап. Обізнаність учнів у характерних рисах листів є ключовою у формуванні писемної компетенції.

Ключові слова: писемна компетентність, комунікативне письмо, мовні вправи, умовно-комунікативні вправи, комунікативні вправи.

Maksymova Olga Pavlivna Candidate of Pedagogic Sciences, Associate Professor of the Department of Languages and Humanities, Department of Languages and Humanities \#2, Donetsk National Medical University, Velyka Perspektyvna St., 1, Kropyvnytskyi, 25000, tel.: (067) 520-14-88, https://orcid.org/0000-0001-8997-4394

Apalat Hanna Pavlivna Candidate of Philological Sciences, Associate Professor of the Department of Germanic Languages and Teaching Methodology, Department of Germanic Languages and Teaching Methodology, Volodymyr Vynnychenko Central Ukrainian State Pedagogical University, Shevchenka St., 1, Kropyvnytskyi, 25006, tel.: (095) 386-03-62, https://orcid.org/0000-0003-1464-7174

\section{WRITING COMPETENCE DEVELOPMENT IN HIGH SCHOOL}

Abstract. Writing competence is an important component of foreign communicative competence. Modern teaching techniques views writing not only as teaching tool but as communication, learning and creativity tool as well. Writing viewed as instrumental tool for teaching foreign language resulted in the lack of practical activities in text books and manuals at each stage of learning communicative writing, in its turn it determined the problem statement of letter writing in high school.

Four approaches are brought forward as for teaching writing of a definite text type at the final stage of studying, namely text, genre, procedural and integrated approaches. The integrated approach which combines the features of the other methods is put forward to teach writing. It comprises teaching language means, thorough study of text models, reader-oriented writing, social oriented writing and discourse production teaching. Preparatory and communicative exercises are offered. The exercise complex for writing of letters of different genres should include two phases: preparatory and communicative. Introductory phase comprises introduction of social standards of formal and informal letter writing. The phase of consolidation involves activities aimed at letters structure studying. The students produce their own letters at the communicative stage.

Writing teaching in high school is aimed at the development of communicative writing. At this period the students are assigned to write a letter to a person they know (according to the situation given). To teach letter writing the complex of exercises includes the introduction, training and communicative stages. It is essential that students should be aware of peculiar features of letter writing to develop writing competence.

Keywords: writing competence, communicative writing, language use activities, communicative activities. 
Журнал«Герспективитаінновації наукиљ

(Серія«Гедагогіка», Серія«Гцихологія», Серія«Медицинв»

№2(7) 2022

Постановка проблеми. Компетентність у письмі є одним із компонентів іншомовної комунікативної компетентності. Значення писемного мовлення у світовій методичній науці зросло в середині 80 -х років XX століття спочатку в методиці навчання рідних мов, потім - іноземних. Це зумовлено змінами в суспільстві, засобах масової комунікації. 3 появою комп'ютера, телефаксу та електронної пошти писемне мовлення стало актуальним засобом спілкування людства. Писемне мовлення $є$ ефективним засобом поглибленого вивчення іноземної мови в умовах відсутності іншомовного середовища; особливості процесу породження писемного мовлення допомагають розвивати відчуття мови в учнів; письмо - один 3 найважливіших каналів пізнання іноземної культури; використання письма на заняттях з іноземної мови має свої методичні переваги, оскільки реально підвищує результат запам'ятовування при закріпленні лексичних та граматичних навичок. Письмо підтримує процес навчання аудіювання, говоріння та читання, дозволяє залучати до роботи одночасно всіх учнів класу і здійснювати індивідуальний контроль їх навичок та умінь, вчить самоконтролю і самокорекції. В сучасній методиці письмо розглядається не лише як засіб навчання, але й як засіб і спосіб спілкування, пізнання та творчості

Розвиток уміння висловлювати думку в писемній формі є завершальним етапом у роботі над письмом. Найбільш розповсюдженою навчальною формою на цьому етапі вважається твір, який може бути у вигляді опису, розповіді, пояснення, міркування [1, с. 213].

Аналіз останніх досліджень і публікацій. Навчання писемного мовлення розглядали вітчизняні та іноземні науковці які займалися проблемами навчання рідної та іноземної мов. До їх числа можна впевнено віднести таких вченихлінгвістів як Д. Аткінсон (D. Atkinson), В. Еванс (V. Evans), А. Херінг (A. Hering), Кр. Сейферт (Ch. Seiffert), Б. Caccep (B. Susser), К.Дж. Топінг (K.J. Topping), A. Яppoy (A. Yarrow).

Було висвітлені такі питання, як інтерактивне навчання писемного мовлення (Ю.В. Колядич [2], Г.Ф. Крівчикова [3]); використання “діалогужурналу” (Т.В. Глазунова [4]); електронного підручника (Т.М. Каменєва [5]); комп’ютерних технологій (О.О. Москалець [6], навчання письма англійською мовою як другою іноземною (І.М. Мельник [7]); використання проектних технологій для навчання письма (С.Д. Сторожук [8]).

Письмо та писемна комунікація раніше розглядалось, як правило, в методиках вивчення іноземних мов як метод навчання, а отже писемна комунікація не була ціллю навчання іноземних мов.

Підхід до писемного мовлення як до допоміжного засобу навчання іноземної мови зумовив недостатню кількість практичних завдань на кожному етапі навчання комунікативного письма у шкільних підручниках та навчальних посібниках, що й зумовило актуальність дослідження.

Мета статті - дослідження особливостей навчання писати листи в старшій школі 
Виклад основного матеріалу. Письмо у широкому розумінні, або писемне мовлення, - специфічний, активний, продуктивний вид мовленнєвої діяльності, який передбачає уміння кодувати інформацію з урахуванням графічного каналу зв'язку. Це - спосіб формування i формулювання думки у письмовій формі $[9 ; 10$, с. 109]. Писемна компетентність є складовою іншомовної комунікативної компетентності.

Іншомовна комунікативна компетентність визначається як сукупність здібностей, знань, умінь, навичок, ставлень, цінностей, ініціатив та комунікативного досвіду особистості, необхідних для розуміння чужих та продукування власних програм мовленнєвої поведінки, адекватних цілям, сферам, ситуаціям спілкування [11, с. 160].

Компетентність у писемному мовленні при написанні листа можливо визначити як здатність та готовність продукувати власне мовлення в жанрі особистий, напівофіційний та офіційний лист, дотримуючись його жанрово стилістичних, змістовних, лексико-граматичних та орфографічних норм.

Завершальний етап $\epsilon$ найважливішим під час засвоєння школярами іноземної комунікації. У навчанні англійської мови чинними є такі стандарти:

- Державний стандарт початкової освіти (2019) [12];

- Державний стандарт базової і повної середньої освіти (2011) [13].

Стандарти визначають вимоги до освіченості учнів відповідно початкової, основної та старшої школи, гарантії держави у ії досягненні.

Навчальна дисципліна "Іноземна мова" входить до освітньої галузі “Мова i література". Змістове наповнення цієї галузі передбачає розвиток особистості учня, формування у нього комунікативної компетентності та загальне уявлення про мову як систему та літературу як вид мистецтва.

Головною метою навчання англійської мови, згідно з Держстандартом, $є$ формування в учнів іншомовної комунікативної компетентності з урахуванням їхніх комунікативних умінь, сформованих на основі відповідних знань i навичок, розвиток умінь спілкуватися в усній та письмовій формах 3 урахуванням мотивів, цілей і соціальних норм мовленнєвої поведінки у типових сферах і ситуаціях.

Державним стандартом визначається базовий рівень сформованості іншомовної комунікативної компетентності на рівні В1 відповідно до Загальноєвропейських Рекомендацій 3 мовної освіти: вивчення, викладання, оцінювання (2003), документ, який спрямований на покращення вивчення, викладання, оцінювання та забезпечення ефективного спілкування між європейцями, які мають різні мови та культуру [14]. Базовий рівень $\epsilon$ комунікативно достатнім і може слугувати надійною основою для подальшого удосконалення комунікативної компетентності. Державний освітній стандарт 3 іноземної мови є основою для укладання програм і підручників 3 англійської мови та визначення концепції навчання англійської мови.

Вивчення англійської мови в старшій школі здійснюється згідно Навчальних програм з іноземних мов для загальноосвітніх навчальних закладів і спеціалізованих шкіл із поглибленим вивченням іноземних мов 10-11 класи [15]. 
Журнал«Герспективитаінновації наукиљ

(Серія«Гедагогіка», Серія«Гцихологія», Серія«Медицинв»

№2(7) 2022

Методисти пропонують чотири підходи до навчання письма певного жанру:

- текстовий;

- жанровий;

- процесуальний;

- інтегрований (дискурсивний).

За текстовим підходом [16, с. 220] передбачається ретельне опрацювання зразків письмових текстів і написання на їх основі власних текстів. Типовою для цього підходу $\epsilon$ така послідовність дій: вивчення тексту-взірця, керована письмова практика, вільні письмові завдання, зворотній зв'язок, робота над помилками. Залежно від завдань окремо чи комплексно здійснюється смисловий, композиційний, мовний, стилістичний аналіз тексту.

Жанровий підхід орієнтований на навчання досягнення різних комунікативних цілей у власних письмових текстах через усвідомлення того, як ці цілі мають досягатися в продуктах різних жанрів [16, с. 221]. Основними характеристиками жанрового підходу є: навчання структур і граматичних особливостей жанру; усвідомлення соціального контексту, який оточує текст; три-етапне створення письмового продукту (імітація, групове обговорення, самостійне конструювання тексту).

Процесуальний підхід зосереджується на процесі створення тексту, його численних доопрацюваннях для досягнення відповідного комунікативного ефекту самим учнем та у співпраці з іншими учнями через коментування робіт один одного [16, с. 221]. Оскільки процесуальний підхід виник під впливом учення когнітивізму, навчання письма побудовано з урахуванням когнітивної переробки інформації та породження письмового висловлювання. Послідовність створення письмового продукту в контексті процесуального підходу передбачає: визначення адресату, постановлення мети, добір матеріалу, його аналіз та організація відповідно до визначеної мети, написання тексту, його критичне читання, редагування, написання кінцевого варіанту, перевірка тексту.

Дискурсивний чи інтегрований підхід [17, с. 246] поєднує риси вищеназваних трьох - навчання мовних засобів, ретельне опрацювання текстівмоделей; навчання письма, орієнтованого на адресата, урахування соціального контексту; навчання поетапного породження дискурсу. У нашому дослідженні ми застосовуємо інтегрований підхід.

Метою навчання писемного мовлення $\epsilon$ формування елементарної комунікативної компетенції, яка забезпечує учневі вміння писемного спілкування в типових ситуаціях. Для навчання писемного мовлення пропонують такі типи вправ:

- підготовчі (мовні й умовно-комунікативні);

- комунікативні (мовленнєві). Вони можуть бути репродуктивними, репродуктивно-продуктивними і продуктивними.

Підготовчі вправи використовують для засвоєння мовного матеріалу у графічному оформленні та для розвитку вмінь логічного і послідовного 
викладення думок. У цих вправах письмо є засобом навчання і вдосконалення граматичних i лексичних навичок i вмінь усного мовлення. До підготовчих вправ належать усі види мовних і умовно-мовленнєвих вправ, які виконують у письмовій формі.

Наприклад, для засвоєння мовного матеріалу виконують такі підготовчі вправи, як: зміна граматичної форми, добір лексичних одиниць, складання речень, об'єднання простих речень у складні, підстановка, трансформація, розширення і завершення мовленнєвих зразків, відповіді на запитання різних типів.

Виконання комунікативних завдань в іншомовному писемному мовленні здійснюється за допомогою уявних навчально-мовленнєвих ситуацій, які потребують розв'язання нестандартних проблем i наближають навчальне спілкування до реальних умов. Під навчально-мовленнєвою ситуацією ми розуміємо запропоновані вчителем умови, необхідні для здійснення учнями мовленнєвої дії відповідно до поставленого комунікативного завдання. Зміст кожної навчально-мовленнєвої ситуації потребує чітко визначеного об'єкту спілкування та конкретного завдання .

Умовно-комунікативні вправи підготовчого етапу можуть включати такі вправи, як

1. мозкова атака (вчитель складає ряд тематично направлених питань, які можуть бути продемонстровані на дошці; кожен учень дає на них відповіді, а вчитель візуалізує їх на дошці для подальшого використання учнями);

2. “clustering” або “mapping” (звуження понять до стрижневих слів із даної теми та розширення понять від стрижневого слова) [18, с. 41];

3. інтерв'ю вважається одним із найпростіших способів акумулювання ідей, тому що учні старшого віку можуть брати інтерв'ю один у одного. Це забезпечує невимушену атмосферу в класі. На проведення відводиться п'ять хвилин, і на написання основних напрямків, здебільшого, п'ятнадцять хвилин. Потім написане учні читають вголос, обговорюють, вчителем корегує, а автор доопрацьовує. Цей прийом усуває появу помилок та допомагає студентам дізнатися більше один про одного;

4. дебати можуть посісти провідне місце серед підготовчих завдань. Згідно з думкою багатьох зарубіжних методистів, усне обговорення завжди має попереджати творче завдання. Воно створює необхідність проектувати зміст i структуру написання [19];

5. усне обговорення дає вчителю змогу з'ясувати, чи володіють студенти в достатній мірі лексичним запасом та потрібними мовними структурами, необхідними для вираження власних думок в писемній формі;

6. групове обговорення найбільш важливе для слабких учнів, оскільки надає їм ідеї та матеріали із запропонованої теми [19, с. 223];

7. груповий твір є гарним прикладом практики, коли клас стає майстернею, а учнів просять працювати малими групами над певним завданням. Взаємодія колективу та вклад кожного учасника є груповою творчістю [20]. 
Не звертаючи уваги на підбір підготовчих завдань, їх задачею $є$ спонукати учнів під час продукування продукту задля написання подальших текстів. Витрачений на подібні діяльності час перекривається кращою якістю творчих доробків авторів-старшокласників.

Для розвитку писемного мовлення важливими є вправи та завдання на розвиток вмінь логічного і послідовного викладення думок та використання зв'язок. Підготовчі вправи для розвитку вмінь логічного і послідовного викладення думок проводять на основі текстів для читання, серії тематичних ілюстрацій або з опорою на ситуацію. Вони можуть бути мовного і умовнокомунікативного характеру.

Мотиваційний етап включає два під-етапи:

- ознайомлення учнів з особливостями жанру;

- ознайомлення зі взірцем-моделлю.

Комунікативні вправи мають продуктивний характер і спрямовані на написання учнями творів, тобто власних письмових висловлювань за темою, на рівні тексту, без використання опор. Комунікативні письмові вправи виконують у середніх і старших класах, за винятком написання листа і листівки, до якого, згідно 3 програмою, залучають учнів 3 3-го класу. Написання творів здійснюється у три етапи:

1. Підготовчий етап (етап планування) - учні збирають фактичний матеріал для твору, розробляють його план, продумують композицію.

2. Мовленнсвий етап (етап формулювання і оформлення задуму) - робота учнів пов'язана із добором слів, кліше, граматичних структур відповідно до змісту твору.

3. Етап контролю - учні перечитують написане, виправляють мовні i стилістичні помилки, вносять зміни у композицію тощо

4. Етап аналізу - вчитель роздає роботи в класі, аналізує листи, виділяючи типові стилістичні, граматичні та лексичні помилки. Учні роблять роботу над помилками.

Відкрите завдання ЗНО передбачає вміння писати листи на запропоновану ситуацію, де кожна ситуація містить три підтеми. Таким чином, учні мають бути готові писати листи за темами, що запропоновані програмою ЗНО, що зумовлює мотивацію учнів стосовно цього виду комунікативної діяльності.

Розвиток писемної компетентності передбачає написання листів різних жанрів. Лист належить до практичного письма. Розрізняють офіційні, напівофіційні та особисті листи. Під час зовнішнього незалежного тестування 3 англійської мови пишуть особистий лист другові. Прикладом напівофіційного листа може бути лист редактору.

Види можливих офіційних листів:

- $\quad$ рекомендаційний лист англійською (letter of recommendation або reference letter);

- лист заява на англійській мові (letter of application);

- $\quad$ лист-скарга (letter of complaint); 
- $\quad$ лист-привітання (letter of congratulation);

- лист-вибачення (letter of apology).

Особисті листи (informal letters) [21] зазвичай пишуть людям, яких добре знають (друзям, родичам тощо), про актуальні новини, особисті проблеми тощо. Під час написання особистого листа учні мають застосовувати неофіційний стиль, для якого характерна розмовна лексика, особистий тон, використання сталих виразів та словосполучень (e.g., drop me a line), використання фразових дієслів та скорочень. Зазвичай виділяють такі види неофіційних листів:

1. Неофіційні листи-запрошення (наприклад, запрошення приїхати до країни та міста того, хто пише, та зупинитися у нього вдома, запрошення взяти участь у якійсь урочистій події приватного характеру: весіллі, ювілеї тощо);

2. Листи-відповіді на запрошення (неофіційні);

3. Листи-обміну новинами (про себе, членів родини, спільних знайомих, події тощо);

4. Листи-вибачення (неофіційне вибачення - найчастіше за довге мовчання 3 поясненням його причин; у цьому випадку вибачення зазвичай сполучається 3 іншим жанром листа, наприклад, з листом-обміном новинами);

5. Поштові картки, інколи листи, з поздоровленнями, привітаннями тощо.

6. Листи-подяки (неофіційна подяка, наприклад, після гостювання в домі адресату, після званого обіду, після проведеного разом часу, подяки за поздоровлення тощо);

7. Листи-прохання дати пораду;

8. Листи з відповіддю на прохання дати пораду та наданням поради;

9. Листи з проханням надати допомогу в вирішенні того чи іншого питання;

10. Листи з відповіддю на прохання надати допомогу в вирішенні того чи іншого питання.

Підсистема вправ для навчання написання листів різних жанрів має включати два етапи: підготовчий та мовленнєвий.

Етап ознайомлення - вправи для вдосконалення навичок читання i розуміння текстів листів та ознайомлення учнів 3 позамовними стандартами написання офіційних та приватних листів: учні знаходять i розпізнають структурні елементи листів, їх коректне розташування.

Етап навчання - застосовуються вправи для формування навичок побудови текстів листів: учні вчаться репродукувати вступну та заключну частини листа, його основну частину, користуючись поданим логічним планом і мовленнєвими зразками, типовими для кожного жанру. Крім того, сюди входять вправи на розпізнавання засобів між фразового зв’язку та їх включення до тексту листа.

Комунікативний етап - включає вправи і завдання на розвиток умінь побудови текстів листів, певних жанрів: учні продукують тексти власних листів.

3 метою покращення писемної компетентності як частини іншомовної комунікативної компетентності і зокрема підготовки до ЗНО учні старшої школи можуть писати листи в кінці кожного модуля за його лексико- 
граматичним матеріалом (в якості тематичного контролю). В рамках повторення, листи потрібно писати за темами ЗНО, після повторення лексикограматичного матеріалу вивчених тем.

Комплекс вправ і завдань, навчання писемного мовлення має включати підготовчі (мовні й умовно-комунікативні) та комунікативні (мовленнєві) вправи та містить підготовчий етап, етап навчання, комунікативний етап, етап контролю та аналізу.

На підготовчому етапі учні дізнаються про / згадують правила написання листа відповідного жанру, ознайомлюються зі зразками листів і кліше. На етапі навчання виконуються вправи на ідентифікацію виду листа, визначення жанрово-стилістичних ознак листа, його структурних та композиційних елементів, аналізуються засоби зв’язку та лексико-граматичні особливості листів певних типів.

Листи пишуться в аудиторії, або виносяться на домашнє завдання (комунікативний етап). Після виконання завдання з письма, вчитель аналізує листи, виділяючи типові стилістичні, граматичні та лексичні помилки та учні роблять роботу над помилками (етап аналізу).

Висновки. Навчання писемної діяльності в старшій школі має на меті розвиток комунікативного письма. На даному етапі учні старших класів виконують завдання: написати лист знайомій людині (за поданою ситуацією). Письмо - це ефективний засіб контролю іншомовних знань, умінь та навичок. Письмові контрольні роботи, застосовуються 3 метою перевірки знань мовного матеріалу, практичних умінь аудіювання, усного висловлювання, читання. Розвиток писемної компетентності передбачає написання листів різних жанрів. Для навчання написання листа застосовується підсистема вправ, що включає етап ознайомлення, етап навчання та комунікативний етап. Обізнаність учнів у характерних рисах листів є ключовою у формуванні писемної компетенції.

\section{Лimepamypa:}

1. Чистякова А. Б. Система вправ при навчанні іноземної мови. Вісник Харківського національного університету імені В.Н. Каразіна. Серія: Викладання мов у вищих навчальних закладах освіти на сучасному етапі. Міжпредметні зв’язки. Харків, 2008. № 12. С. 208-214.

2. Колядич Ю. В. Інтерактивна організація процесу навчання англійського писемного мовлення [Електронний ресурс]. 2018. Режим доступу: https://journals.indexcopernicus.com/api/ file/viewByFileId/908269.pdf

3. Крівчикова Г. Ф. Інтерактивне навчання іншомовного писемного мовлення студентів мовних спеціальностей. Науково-методичний журнал “Іноземні мови”. 2002. № 3. С. 17-20.

4. Глазунова Т. В. Види письмових висловлювань як об’єкт навчання. Науковометодичний журнал “Іноземні мови”. 1997. № 1. С. 61-62.

5. Каменева Т. Н. Разработка электронного учебника как компонента информационного образовательного пространства [Электронный ресурс]. Международный электронный журнал «Образовательные технологии и общество». 2012. Режим доступа: https://readera.org/14062411

6. Москалець О. О. Навчання студентів-філологів письма англійською мовою 3 використанням комп’ютерних технологій: дис. ... канд. пед. наук: спец. 13.00.02. Київ, 2009. 274 с.

7. Мельник I. М. Навчання студентів-філологів письма англійською мовою як другою іноземною (перший рік навчання): автореф. дис. ... канд. пед. наук: спец. 13.00.02. Київ, 2001. 19 с. 
8. Сторожук С. Д. Формування писемної комунікативної компетентності майбутніх викладачів англійської мови на основі проєктних технологій: дис. ... канд. пед. наук : спец. 13.00.02. Дніпро, 2020. 361 с.

9. Зимняя И. А. Психология обучения иностранным языкам в школе. Москва: Просвещение, 1991. 222 с.

10. Ніколаєва С. Ю. Сучасні підходи до викладання іноземних мов. Науковометодичний журнал “Іноземні мови”. 2002. № 1. С. 39-46.

11. Бідюк Н. М. Комунікативна компетентність майбутнього вчителя філолога: зміст та структура. "Інформаційно-комунікаційні технології в сучасній освіті: досвід, проблеми, перспективи": збірник наукових праць третьої Міжнародної науково-практичної конференції (Київ-Львів, 12-14 листопада 2012 р.): у 2 ч. / за ред. М.М. Козяра, Н.Г. Ничкало. - Львів: Львівський державний університет безпеки життєдіяльності, 2012. - Ч. 2. - С. 158-160.

12. Державний стандарт початкової освіти, затверджений Постановою Кабінету Міністрів України від 21 лютого 2018 р. № 87 (у редакції постанови Кабінету Міністрів України від 24 липня 2019 р. № 688) [Електронний ресурс]. Режим доступу: https://zakon.rada.gov.ua/laws/show/87-2018-\%D0\%BF\#Text

13. Державний стандарт базової і повної середньої освіти, затверджений Постановою Кабінету Міністрів України від 23 листопада 2011 року № 1392 [Електронний ресурс]. Режим доступу: https://zakon.rada.gov.ua/laws/show/898-2020-\%D0\%BF\#Text

14. Загальноєвропейські Рекомендації 3 мовної освіти: вивчення, викладання, оцінювання / Науковий редактор українського видання доктор пед. наук, проф. С.Ю. Ніколаєва. К.: Ленвіт, 2003. 273 с.

15. Навчальні програми 3 іноземних мов для загальноосвітніх навчальних закладів i спеціалізованих шкіл із поглибленим вивченням іноземних мов 10-11 класи. [Електронний peсурс]. Київ, 2017. Режим доступу: mon.gov.ua/storage/app/media/zagalna\%20serednya/ programy-10-11-klas/2018-2019/inozemni-movi-10-11-19.09.2017.pdf

16. Тарнопольський О. Б. Методика навчання іншомовної мовленнєвої діяльності у вищому мовному закладі освіти: навч. посібник. К.: Інкос, 2006. 248 с.

17. Задорожна I. П. Теоретико-методичні засади організації самостійної роботи майбутніх учителів з оволодіння англомовною комунікативною компетенцією: дис. ... д-ра пед. наук: спец. 13.00.02. Київ, 2012. 770 с.

18. Методика викладання іноземних мов у середніх навчальних закладах: Підручник. Вид. 2-е, випр. і перероб. / Кол. авторів під керівн. С.Ю. Ніколаєвої. К.: Ленвіт, 2002. 328 с.

19. Hubert M. D. The speaking-writing connection: integrating dialogue into a foreign language writing course. Electronic Journal of Foreign Language Teaching. 2011. Vol. 8, No. 2. P. 170-183.

20. Teo A. SWELL: a writing method to help English language learners. English teaching forum. 2007. [Електронний ресурс]. Режим доступу: https://americanenglish.state.gov/files/ ae/resource_files/07-45-4-d.pdf

21. Види власних висловлювань на ЗНО з англійської мови [Електронний ресурс]. Режим доступу: https:/osvita.ua/test/training/english/55354/

\section{References:}

1. Chystiakova, A. B. (2008). Systema vprav pry navchanni inozemnoi movy [System of exercises in foreign language teaching]. Visnyk Kharkivskoho natsionalnoho universytetu imeni V.N. Karazina. Seriia: Vykladannia mov u vyshchykh navchalnykh zakladakh osvity na suchasnomu etapi. Mizhpredmetni zviazky - Bulletin of V.N. Karazin Kharkiv National University.- Ser.: Teaching languages at higher education institutions in modern times. Interdisciplinary relationships, issue 12, pp. 208-214. Kharkiv [in Ukrainian].

2. Koliadych, Yu. V. (2018). Interaktyvna orhanizatsiia protsesu navchannia anhliiskoho pysemnoho movlennia [Interactive organization of the English written lesson training process]. Retrieved from https://journals.indexcopernicus.com/api/file/viewByFileId/908269.pdf [in Ukrainian]. 
3. Krivchykova, G. F. (2002). Interaktyvne navchannia inshomovnoho pysemnoho movlennia studentiv movnykh spetsialnostei [Interactive teaching of writing in a foreign language to linguistic specialties' students]. Naukovo-metodychnyi zhurnal "Inozemni movy" - Scientific and methodical journal "Foreign languages", issue 3, pp. 17-20 [in Ukrainian].

4. Glazunova, T. V. (1997). Vydy pysmovykh vyslovliuvan yak obiekt navchannia [Types of written statements as a learning object]. Naukovo-metodychnyi zhurnal "Inozemni movy" Scientific and methodical journal "Foreign languages", issue 1, pp. 61-62 [in Ukrainian].

5. Kameneva, T. N. (2012). Razrabotka ehlektronnogo uchebnika kak komponenta informatsionnogo obrazovatel'nogo prostranstva [Development of an electronic textbook as a component of the information and education space]. Mezhdunarodnyj ehlektronnyj zhurnal "Obrazovatel'nye tekhnologii $i$ obshhestvo" - International online journal "Educational Technology \& Society”. Retrieved from https://readera.org/14062411 [in Russian].

6. Moskalets, O. O. (2009). Navchannia studentiv-filolohiv pysma anhliiskoiu movoiu z vykorystanniam kompiuternykh tekhnolohii [Teaching the students of language departments English writing with the help of computer technologies]. Candidate's thesis. Kyiv: Kyiv National Linguistic University [in Ukrainian].

7. Melnyk, I. M. (2001). Navchannia studentiv-filolohiv pysma anhliiskoiu movoiu yak druhoiu inozemnoiu (pershyi rik navchannia) [Teaching the students of language departments English writing as a second foreign language (first-year studies)]. Extended abstract of candidate's thesis. Kyiv: Kyiv National Linguistic University [in Ukrainian].

8. Storozhuk, S. D. (2020). Formuvannia pysemnoi komunikatyvnoi kompetentnosti maibutnikh vykladachiv anhliiskoi movy na osnovi proiektnykh tekhnolohii [Developing prospective English teachers' communicative competence in writing on the basis of project technologies]. Candidate's thesis. Dnipro: Alfred Nobel University [in Ukrainian].

9. Zimnyaya, I. A. (1991). Psikhologiya obucheniya inostrannym yazykam v shkole [Psychology of teaching foreign languages at high school]. Moscow: Prosveshchenie [in Russian].

10. Nikolaieva S. Yu. (2002). Suchasni pidkhody do vykladannia inozemnykh mov [Modern approaches to teaching foreign languages]. Naukovo-metodychnyi zhurnal "Inozemni movy" Scientific and methodical journal "Foreign languages", issue 1, pp. 39-46 [in Ukrainian].

11. Bidiuk N. M. (2012). Komunikatyvna kompetentnist maibutnoho vchytelia filoloha: zmist ta struktura [Communicative competence of the prospective teacher of philology: content and structure]. M.M. Koziara, N.H. Nychkalo (Eds.), Informatsiino-komunikatsiini tekhnolohii v suchasnii osviti: dosvid, problemy, perspektyvy - Information and Communication Technologies in Modern Education: Experience, Problems, Prospects: Proceedings of the 3rd International Scientific and Practical Conference (part 2), (pp. 158-160). Lviv: Lviv State University of Life Safety [in Ukrainian].

12. Derzhavnyi standart pochatkovoi osvity [State Standard of Primary Education]. Postanova Kabinetu Ministriv Ukrainy № 87 vid 21.02.2018 (u redaktsii Postanovy Kabinetu Ministriv Ukrainy № 688 vid 24.07.2019 r.) - Resolution of the Cabinet of Ministers of Ukraine № 87 dated 21.02.2018 (as amended by the Resolution of the Cabinet of Ministers of Ukraine № 688 dated 24.07.2019). (n.d.). zakon.rada.gov.ua. Retrieved from https://zakon.rada.gov.ua/laws/show/872018-\%D0\%BF\#Text [in Ukrainian].

13. Derzhavnyi standart bazovoi i povnoi serednoi osvity [State Standard of Basic and Complete Secondary Education]. Postanova Kabinetu Ministriv Ukrainy № 1392 vid 23.11.2011 - Resolution of the Cabinet of Ministers of Ukraine № 1392 dated 23.11.2011). (n.d.). zakon.rada.gov.ua. Retrieved from https://zakon.rada.gov.ua/laws/show/898-2020-\%D0\%BF\#Text [in Ukrainian].

14. Nikolaieva, S. Yu. (Ed.). (2003). Zahalnoievropeiski Rekomendatsii z movnoi osvity: vyvchennia, vykladannia, otsiniuvannia [The Common European Framework of Reference for Languages: Learning, Teaching, Assessment]. Kyiv: Lenvit [in Ukrainian].

15. Navchalni prohramy z inozemnykh mov dlia zahalnoosvitnikh navchalnykh zakladiv i spetsializovanykh shkil iz pohlyblenym vyvchenniam inozemnykh mov 10-11 klasy [Foreign languages curricula for general educational institutions and specialized schools with advanced foreign languages learning, grades 10-11]. (2017). Retrieved from mon.gov.ua/storage/app/ media/zagalna\% 20serednya/programy-10-11-klas/2018-2019/inozemni-movi-10-11-19.09.2017.pdf [in Ukrainian]. 
16. Tarnopolskyi, O. B. (2006). Metodyka navchannia inshomovnoi movlennievoi diialnosti u vyshchomu movnomu zakladi osvity: navch. posibnyk [Methods of teaching foreign language speech activity in a language higher education institution: textbook]. Kyiv: Inkos [in Ukrainian].

17. Zadorozhna, I. P. (2012). Teoretyko-metodychni zasady orhanizatsii samostiinoi roboty maibutnikh uchyteliv z ovolodinnia anhlomovnoiu komunikatyvnoiu kompetentsiieiu [Theoretical and methodological foundations of future teachers' self-study work organization on acquiring communicative competence in English]. Doctor's thesis. Kyiv: Kyiv National Linguistic University [in Ukrainian].

18. Nikolaieva, S. Yu. (Eds.). (2002). Metodyka vykladannia inozemnykh mov u serednikh navchalnykh zakladakh: Pidruchnyk [Methods of teaching foreign languages in secondary education institutions: textbook]. Vyd. 2-e, vypr. i pererob. -2 nd ed., rev. Kyiv: Lenvit [in Ukrainian].

19. Hubert, M. D. (2011). The speaking-writing connection: integrating dialogue into a foreign language writing course. Electronic Journal of Foreign Language Teaching. (Vol. 8, No. 2), pp. 170-183 [in English].

20. Teo, A. (2007). SWELL: a writing method to help English language learners. English teaching forum. Retrieved from https://americanenglish.state.gov/files/ae/resource_files/07-45-4-d.pdf [in English].

21. Vydy vlasnykh vyslovliuvan na ZNO z anhliiskoi movy [Types of own statements at the External independent testing in English]. (2020). Retrieved from https://osvita.ua/test/training/ english/55354/ [in Ukrainian]. 